\title{
EVALUATION OF SOYBEAN MEAL AS A PROTEIN SOURCE AND ITS EFFECT ON GROWTH AND NITROGEN UTILIZATION OF BLACK SEA TURBOT (PSETTA MAEOTICA) JUVENILES
}

\author{
Murat Yigit \\ muratyigit2@hotmail.com \\ Sebahattin Ergün \\ Ali Türker \\ Department of Aquaculture, Faculty of Fisheries, Muğla University, Muğla, Turkey \\ Burcu Harmantepe \\ Department of Aquaculture, Faculty of Fisheries, Sinop University, Sinop, Turkey \\ Adnan Erteken \\ Central Fisheries Research Institute, Yomra, P. K. 129, Trabzon, Turkey
}

Department of Aquaculture, Faculty of Fisheries, Çanakkale Onsekiz Mart University, Çanakkale, Turkey.,

Department of Aquaculture, Faculty of Fisheries, Çanakkale Onsekiz Mart University, Çanakkale, Turkey

Follow this and additional works at: https://jmstt.ntou.edu.tw/journal

Part of the Aquaculture and Fisheries Commons

\section{Recommended Citation}

Yigit, Murat; Ergün, Sebahattin; Türker, Ali; Harmantepe, Burcu; and Erteken, Adnan (2010) "EVALUATION OF SOYBEAN MEAL AS A PROTEIN SOURCE AND ITS EFFECT ON GROWTH AND NITROGEN UTILIZATION OF BLACK SEA TURBOT (PSETTA MAEOTICA) JUVENILES," Journal of Marine Science and Technology. Vol. 18: Iss. 5, Article 8.

DOI: $10.51400 / 2709-6998.1913$

Available at: https://jmstt.ntou.edu.tw/journal/vol18/iss5/8

This Research Article is brought to you for free and open access by Journal of Marine Science and Technology. It has been accepted for inclusion in Journal of Marine Science and Technology by an authorized editor of Journal of Marine Science and Technology. 


\section{EVALUATION OF SOYBEAN MEAL AS A PROTEIN SOURCE AND ITS EFFECT ON GROWTH AND NITROGEN UTILIZATION OF BLACK SEA TURBOT (PSETTA MAEOTICA) JUVENILES}

\section{Acknowledgements}

We are very grateful to Prof. Dr. Muammer ERDEM (Dean of Fisheries Faculty, Ondokuz Mayis University, Sinop-Turkey) for his valuable advice and support throughout the study. The authors wish to acknowledge JAPAN International Cooperation Agency (JICA), Trabzon Central Fisheries Research Institute (CFRI), and Assoc. Prof. Dr. Emin ÖZDAMAR from JICA Office in Ankara, Turkey, for supporting the experimental animals. We wish to thank Abalioglu Feed Company in Denizli-Turkey for donating the soybean meal product used in the study 


\title{
EVALUATION OF SOYBEAN MEAL AS A PROTEIN SOURCE AND ITS EFFECT ON GROWTH AND NITROGEN UTILIZATION OF BLACK SEA TURBOT (PSETTA MAEOTICA) JUVENILES
}

\author{
Murat Yigit*, Sebahattin Ergün*, Ali Türker**, Burcu Harmantepe***, \\ and Adnan Erteken****
}

Key words: Black Sea turbot, fish meal, nitrogen retention, soybean meal.

\section{ABSTRACT}

Three experimental diets were formulated to be isonitrogenous (550 $\mathrm{g} \mathrm{kg}^{-1}$ protein) and iso-caloric $(20.5 \mathrm{~kJ}$ gross energy $\mathrm{g}^{-1}$ diet) by substituting fish meal (FM) for defatted soybean meal (SBM) at levels of 0,10 and $20 \%$ replacement in order to evaluate the effects of replacing FM with defatted SBM in diets for Black Sea turbot. Diets were fed to triplicate groups of young Black Sea turbot (mean initial weight of $30.2 \pm 0.2 \mathrm{~g}$ ) for 60 days. Turbot fed all three diets had no significant difference $(P>0.05)$ in final weight, specific growth rate, nutrient utilization, Nitrogen loss or retention. Survival rate was $100 \%$ in all treatments. The results of this study indicate that fish meal can be replaced with soybean meal up to $20 \%$ level in diets for young Black Sea turbot without adverse effects on growth, nutrient utilization or nitrogen balance. This may increase profitability by allowing the production of less expensive feeds, hence supporting the sustainable growth of turbot culture industry with environment-friendly diets.

\section{INTRODUCTION}

The demand for fish meal (FM) in the world aquaculture industry was $68.2 \%$ of the total global fish meal production in

Paper submitted 01/16/09; revised 07/28/09; 08/28/09; accepted 09/14/09. Author for correspondence: Murat Yigit (e-mail: muratyigit2@ hotmail.com). This paper is an extended version of an oral presentation at Aquaculture Europe 2007, Abstract p. 611-612. Istanbul, Turkey, 24-27 October, 2007.

*Department of Aquaculture, Faculty of Fisheries, Çanakkale Onsekiz Mart University, Çanakkale, Turkey.

**Department of Aquaculture, Faculty of Fisheries, Muğla University, Muğla, Turkey.

***Department of Aquaculture, Faculty of Fisheries, Sinop University, Sinop, Turkey.

****Central Fisheries Research Institute, Yomra, P. K. 129, Trabzon, Turkey. year 2006 [39]. A gradual decline of wild fish catch as protein source for fish feed production has been reported as essential for the sustainable development of the aquaculture Industry [29]. Due to the limiting supply of FM in the world, fish nutritionists have intensified their search on replacing FM by less expensive alternative protein sources. Based on the increase of global fish meal costs, Tacon and Metian [39] reported that fish meal usage in compound aquafeeds will decrease in the long term. High protein requirement $\left(500 \mathrm{~g} \mathrm{~kg}^{-1}\right.$ to $600 \mathrm{~g}$ $\mathrm{kg}^{-1}$ of the diet) has been reported for the turbot, an important fish species for the European aquaculture industry $[5,7,18)$. Hence, the partial replacement of the fish meal with proteinrich ingredients is therefore an important and interesting issue to focus on. Previous studies with turbot have focused on some plant protein sources such as corn gluten meal, lupin or soybean meal $[6,10,14,32]$. Among several protein sources, soybean meal (SBM) is considered as one of the most nutritious because of its favorable protein content and amino acid profile. The use of soy products has been widely studied in a number of fish species. Soybean meal has been tested in diets for Japanese flounder [23, 24, 27], Yellowtail [35-38, 49], Atlantic halibut [4], European sea bass [16, 43], gilthead sea bream [25, 29, 34], and red sea bream [2, 3, 40, 41]. However, little work has been done on the effectiveness of soy products in Atlantic turbot (Psetta maxima) [10], and to our knowledge, so far, there are only few studies available on the evaluation of soybean meal as a dietary protein source for the Black Sea turbot $[11,12,20]$. The objective of this study, therefore, is to evaluate the effects of substituting fish meal (FM) with defatted soybean meal (SBM) in practical diets on growth performance, nutrient utilization and nitrogen balance of young Black Sea turbot.

\section{MATERIALS AND METHODS}

Three practical diets (iso-nitrogenous and iso-caloric) on a crude protein of $550 \mathrm{~g} \mathrm{~kg}^{-1}$ and gross energy of $20.5 \mathrm{~kJ} \mathrm{~g}^{-1}$ diet basis were formulated with commercially available ingredients 
Table 1. Ingredients and nutrient composition of diets used in the experiment.

\begin{tabular}{|c|c|c|c|}
\hline \multirow[t]{2}{*}{ Ingredients $\left(\mathrm{g} \mathrm{kg}^{-1}\right)$} & \multicolumn{3}{|c|}{ Replacement level (\%) } \\
\hline & 0 & 10 & 20 \\
\hline White fish meal (FM) & 773 & 706 & 638 \\
\hline SBM & 0 & 100 & 200 \\
\hline Fish oil & 79 & 82 & 85 \\
\hline b-Corn starch & 90 & 54 & 20 \\
\hline Vit.-Min. Premix ${ }^{a}$ & 35 & 35 & 35 \\
\hline Attractant $^{\mathrm{b}}$ & 3 & 3 & 3 \\
\hline Binder (Guar-Gum) & 20 & 20 & 20 \\
\hline \multicolumn{4}{|c|}{ Proximate composition ( $\mathrm{g} \mathrm{kg}^{-1}$ on dry basis) } \\
\hline Dry matter & 920.3 & 913.6 & 923.4 \\
\hline Crude Lipid & 152.6 & 161.9 & 160.4 \\
\hline Crude Ash & 130.9 & 132.1 & 129.4 \\
\hline Crude Protein & 549.3 & 546.3 & 547.9 \\
\hline Nitrogen free extracts ${ }^{c}$ & 87.5 & 73.3 & 85.7 \\
\hline $\mathrm{GE}\left(\mathrm{kJ} \mathrm{g}^{-1} \text { diet }\right)^{\mathrm{d}}$ & 20.52 & 20.57 & 20.76 \\
\hline $\mathrm{P}: \mathrm{E}\left(\mathrm{mg} \mathrm{kJ}^{-1}\right)^{\mathrm{e}}$ & 26.77 & 26.55 & 26.39 \\
\hline Total n-3 HUFA & 36.2 & 36.0 & 35.6 \\
\hline
\end{tabular}

${ }^{a}$ Kadai, Riken Vitamin, Tokyo, Japan

${ }^{\mathrm{b}}$ Glutamic acid, 0.9; Inosine, 0.1 (Sigma, Germany)

${ }^{\mathrm{c}}$ Calculated by difference

${ }^{\mathrm{d}}$ Gross Energy calculated according to $23.6 \mathrm{~kJ} \mathrm{~g}^{-1}$ protein, $39.5 \mathrm{~kJ} \mathrm{~g}^{-1}$ lipid, $17 \mathrm{~kJ} \mathrm{~g}^{-1}$ nitrogen-free extract.

${ }^{\mathrm{e}}$ Protein to Energy ratio

Table 2. Essential amino acid contents in the experimental diets.

\begin{tabular}{lcccc}
\hline \multirow{2}{*}{$\begin{array}{l}\text { Amino acid content } \\
\left(\mathrm{g} \mathrm{kg}^{-1} \mathrm{DM}\right)^{\mathrm{a}}\end{array}$} & \multicolumn{3}{c}{ Experimental diets } & Turbot \\
\cline { 2 - 4 } & FM100 & SBM10 & SBM20 & Requir. $^{\text {b }}$ \\
\hline Arg & 34.1 & 34.5 & 35.0 & 35.9 \\
Lys & 38.3 & 38.1 & 37.8 & 34.2 \\
His & 11.4 & 11.6 & 11.9 & 14.7 \\
Ile & 23.0 & 24.0 & 24.9 & 18.4 \\
Leu & 36.9 & 37.8 & 38.5 & 32.5 \\
Val & 25.6 & 25.9 & 26.2 & 21.1 \\
Met + Cys & 20.6 & 20.1 & 19.7 & 22.7 \\
Phe + Tyr & 34.8 & 35.9 & 37.1 & 39.0 \\
Thr & 21.8 & 21.8 & 21.8 & 21.2 \\
Trp & 5.6 & 5.8 & 6.0 & N/A \\
\hline
\end{tabular}

${ }^{a}$ Essential amino acid contents calculated from data in Table 3.

${ }^{\mathrm{b}}$ Data on amino acid requirements of turbot are from Kaushik [21].

and produced at the Central Fisheries Research Institute (CFRI) in Trabzon, Turkey. White fish meal (high quality whiting meal, $710 \mathrm{~g} \mathrm{~kg}^{-1}$ crude protein) was the sole protein source in the control diet, as suggested by Yigit et al. [51] for Black Sea turbot diets. The test diets were formulated by substituting FM for defatted SBM at levels of $0 \%, 10 \%$ and $20 \%$ replacement. Ingredient and chemical composition of the diets are presented in Table 1. Total n-3 HUFA contents were calcu-
Table 3. Proximate composition of white fish meal, soybean meal, and turbot.

\begin{tabular}{lccr}
\hline Proximate analyses $\left(\mathrm{g} \mathrm{kg}^{-1}\right)$ & Turbot & WFM & SBM \\
\hline Moisture & & 80 & 110 \\
Protein & & 714 & 480 \\
Lipid & & 55 & 10 \\
Ash & 120 & 60 \\
\hline Essential amino acid $\left(\mathrm{g} \mathrm{kg}^{-1}\right)^{*}$ & & & \\
Arg & 65.3 & 44.1 & 34.1 \\
Lys & 62.2 & 49.6 & 31.0 \\
His & 26.7 & 14.7 & 12.6 \\
Ile & 33.5 & 29.8 & 29.2 \\
Leu & 59.1 & 47.8 & 40.2 \\
Val & 38.4 & 33.1 & 25.3 \\
Met & N/A & 18.4 & 7.2 \\
Cys & N/A & 8.2 & 6.3 \\
$\quad$ Met + Cys & 41.2 & 26.6 & 13.5 \\
Phe & N/A & 25.0 & 24.5 \\
Tyr & N/A & 20.0 & 17.2 \\
Phe + Tyr & 70.9 & 45.0 & 41.7 \\
Thr & 38.6 & 28.2 & 19.2 \\
Trp & N/A & 7.3 & 6.8 \\
\hline
\end{tabular}

N/A = not available. $*$ Data on amino acid content of white fishmeal and soybean meal are from Halver [19].

lated according to the equation [51] given below and ranged from $35.6 \mathrm{~g} \mathrm{~kg}^{-1}$ for the diet containing the lowest amount of FM to $36.2 \mathrm{~g} \mathrm{~kg}^{-1}$ for the diet containing FM as the sole protein source (Table 1). The amino acid profiles of the diets were estimated according to Kaushik [21] and reported in Table 2. Nutrient composition and amino acid profiles of protein sources and turbot are given in Table 3 .

Total n-3 HUFA in diet, $\mathrm{g} \mathrm{kg}^{-1}$

$=\left(\right.$ total fish oil in diet, $\left.\mathrm{g} \mathrm{kg}^{-1}\right) \times(\% \mathrm{n}-3$ HUFA in fish oil used $)$

All dry ingredients were mixed together with oil in a food mixer for $15 \mathrm{~min}$. Thereafter tap water was blended into the mixture to attain a consistency appropriate for passing through a meat grinder with a $3 \mathrm{~mm}$ holes die. After pelleting, the diets were dried to a moisture content of $80-100 \mathrm{~g} \mathrm{~kg}^{-1}$ and cool stored in a refrigerator until the start of the experiment.

Hatchery reared Black Sea turbot (Psetta maeotica) with mean weight of $30.2 \pm 0.2 \mathrm{~g}$ were obtained from the Central Fisheries Research Institute (CFRI) in Trabzon, Turkey, and transported to the marine facility of the Faculty of Fisheries, Sinop University (formerly Ondokuz Mayis University) in Sinop, Turkey. Prior to the experiment, the fish were fed a commercial fish meal-based diet $\left(550 \mathrm{~g} \mathrm{~kg}^{-1}\right.$ crude protein, 160 $\mathrm{g} \mathrm{kg}^{-1}$ crude lipid, $90 \mathrm{~g} \mathrm{~kg}^{-1}$ nitrogen-free extract (NFE), $21 \mathrm{~kJ}$ gross energy $\mathrm{g}^{-1}$ diet and $26.2 \mathrm{mg}$ protein $\mathrm{kJ}^{-1}$ energy) to sa- 
Table 4. Growth performance and feed utilization of Black Sea turbot fed test diets for 60 days.

\begin{tabular}{lrrr}
\hline & \multicolumn{3}{c}{ Experimental diets } \\
\cline { 2 - 4 } & \multicolumn{1}{c}{ FM100 } & \multicolumn{1}{c}{ SBM10 } & \multicolumn{1}{c}{ SBM20 } \\
\hline IBW (g) & $30.22 \pm 0.06^{\mathrm{a}}$ & $30.17 \pm 0.07^{\mathrm{a}}$ & $30.22 \pm 0.23^{\mathrm{a}}$ \\
FBW (g) & $71.98 \pm 3.44^{\mathrm{a}}$ & $71.61 \pm 3.30^{\mathrm{a}}$ & $70.11 \pm 3.45^{\mathrm{a}}$ \\
SGR $\left(\%\right.$ day $\left.^{-1}\right)$ & $1.45 \pm 0.08^{\mathrm{a}}$ & $1.44 \pm 0.07^{\mathrm{a}}$ & $1.40 \pm 0.07^{\mathrm{a}}$ \\
FI $\left(\%\right.$ day $\left.^{-1}\right)$ & $1.072 \pm 0.01^{\mathrm{a}}$ & $1.069 \pm 0.02^{\mathrm{a}}$ & $1.065 \pm 0.02^{\mathrm{a}}$ \\
FCR & $0.86 \pm 0.03^{\mathrm{a}}$ & $0.86 \pm 0.06^{\mathrm{a}}$ & $0.87 \pm 0.05^{\mathrm{a}}$ \\
PER & $2.31 \pm 0.09^{\mathrm{a}}$ & $2.32 \pm 0.15^{\mathrm{a}}$ & $2.27 \pm 0.13^{\mathrm{a}}$ \\
\hline
\end{tabular}

Values (means \pm standard deviation of data for triplicate groups) with different superscripts in the same row are significantly different at $5 \%$ level. IBW = Initial body weight, $\mathrm{FBW}=$ Final body weight.

SGR, Specific growth rate (percent increase in body weight per day $)=[(\ln$ final wet weight $-\ln$ initial wet weight $) /$ days $] \times 100$

FI, feed intake (percent body weight per day) $=$ (total feed distributed/((initial weight + final weight $) / 2) /$ days $) \times 100$

FCR, Feed conversion ratio $=$ feed/wt gain

PER, Protein efficiency ratio = wet wt gain/protein intake

tiation once a day for one month allowing the fish to acclimate to the new environment.

Experimental fish were then randomly distributed into 9 identical 60 -L rectangular polypropylene tanks filled with 45 L water (12 fish per tank with three replicate tanks per treatment). In an indoor flow-through system, seawater $\left(17 \mathrm{~g} \mathrm{~L}^{-1}\right.$ salinity) was supplied to the tanks at a flow rate of $1.5 \mathrm{~L} \mathrm{~min}^{-1}$. Continuous aeration was provided by air-stones. Fish were exposed to natural light regime $\left(35^{\circ} 09^{\prime} \mathrm{E} 42^{\circ} 01^{\prime} \mathrm{N}\right)$. The experimental tanks were cleaned daily to remove uneaten feed and fecal material. Water quality was checked periodically; $\mathrm{pH}$ ranged from 7.5-8, total ammonia nitrogen determined by the Nessler method using a HANNA C200 portable spectrophotometer (HANNA Instruments, Co., Italy) varied 0.24-0.28 $\mathrm{mg} \mathrm{L}^{-1}$. Water temperature was seawater ambient, ranging between 14 and $24^{\circ} \mathrm{C}$ during the course of the 60-days trial carried out from May to June 2003. Fish were hand fed twice daily at 9:00 and 18:00 h. Feeding activity was monitored carefully in order to attain an even distribution of the feed given among all fish in each tank. All fish were individually weighed at the start of the experiment, and at the end of the experiment (day 60).

At the start of the experiment, 15 fish from an initial pool of fish were sampled, anesthetized and thereafter stored in polyethylene bags and frozen $\left(-20^{\circ} \mathrm{C}\right)$ for analysis of muscle composition. At the end of the trial, three fish per tank were randomly withdrawn for comparative analysis of fish muscle (dry matter, protein, lipid, ash) and calculation of nutrient retention rates. Samples were prepared for analyses by homogenizing the muscle tissue of fish in a blender prior to the analyses, conducted in triplicate. Muscle tissues sampled between the lateral line and the dorsal fin from both sides of the fish were used for the analyses. Chemical analyses of diets and fish muscle tissue were performed according to AOAC [1] guidelines as follows: dry matter after drying in an oven at $105^{\circ} \mathrm{C}$ for $24 \mathrm{~h}$ until constant weight, protein $(\mathrm{N} \times 6.25)$ by the Kjeldahl method after acid digestion, lipids by ethyl ether extraction in a Soxhlet System, ash by incineration in a muffle furnace at $550^{\circ} \mathrm{C}$ for $12 \mathrm{~h}$, while NFE was calculated by difference.

Calculation of the specific growth rate, feed conversion rate, protein efficiency rate, total nitrogen loss and retention rates were performed as described by Watanabe et al. [47, 48], Burel et al. [6] and Yigit et al. [52].

The Kolmogorov-Smirnov and Levene statistic tests were applied to test normality and homogenity of variance, respectively. Analysis of variance and the Duncan multiple-range test were used to detect significant differences $(P<0.05)$ in final body weight, specific growth rate, feed intake, feed conversion rate, protein efficiency rate, nitrogen balance and proximate muscle composition. All statistical analyses were performed using the SPSS Statistical Analysis Software Program for Windows, Version 10.0.1, 1999.

\section{RESULTS}

Survival was $100 \%$ in all experimental groups. Mean final body weights, relative growth rate and feed utilization data are shown in Table 4. Even though the highest growth rate was obtained in turbot fed diet with $100 \%$ fish meal, no significant differences $(P>0.05)$ were found among the experimental groups. Similarly, Specific growth rate (SGR), feed conversion rate (FCR), and protein efficiency rates (PER) did not differ significantly $(P>0.05)$ among groups (Table 4$)$.

Total nitrogen loss per net wet gain was not significantly different $(P>0.05)$ among the experimental groups, even though a slight decline could be seen when dietary SBM increased and FM decreased. In a similar manner, total nitrogen loss as a percent of the nitrogen consumption slightly increased, as the FM replacement levels rose, but no significance was recorded $(P>0.05)$ (Table 5).

Overall, the muscle tissue moisture, crude protein, crude lipid and crude ash of fish did not show any significant difference among the experimental groups. The muscle tissue moisture of fish fed the diets with SBM inclusion showed a slight increase, when compared to fish fed the reference diet, but no significant difference was recorded $(P>0.05)$. Conversely to muscle tissue moisture, crude lipid of fish muscle tissue tended to decrease slightly as dietary SBM increased, but no significant difference was observed $(P>0.05)$. The muscle protein of fish fed diet with SBM inclusion tended to decrease slightly, when compared to fish fed the control diet with FM only, however this decline was also not significant $(P$ $>0.05)$. Similarly, ash levels of fish muscle tissue of fish did not show any significant difference $(P>0.05)$ among treatment groups (Table 6).

\section{DISCUSSION}

The response to dietary soybean incorporation differs among 
Table 5. Nitrogen utilization of Black Sea turbot fed to satiation the experimental diets for 60 days.

\begin{tabular}{|c|c|c|c|}
\hline & \multicolumn{3}{|c|}{ Experimental diets } \\
\hline & FM100 & SBM10 & SBM20 \\
\hline $\begin{array}{l}\mathrm{TNI} \text { (mg N g}{ }^{-1} \\
\text { production) }\end{array}$ & $69.32 \pm 3.69^{\mathrm{a}}$ & $69.04 \pm 4.46^{\mathrm{a}}$ & $70.66 \pm 4.26^{\mathrm{a}}$ \\
\hline Nitr. diet (\%) & 8.79 & 8.74 & 8.77 \\
\hline Nitr. in fish (\%) & $2.78 \pm 0.03^{\mathrm{a}}$ & $2.77 \pm 0.01^{\mathrm{a}}$ & $2.75 \pm 0.03^{\mathrm{a}}$ \\
\hline $\mathrm{TNL}\left(\mathrm{mg} \mathrm{g}^{-1}\right)$ & $40.75 \pm 1.05^{\mathrm{a}}$ & $40.52 \pm 2.00^{\mathrm{a}}$ & $42.39 \pm 1.95^{\mathrm{a}}$ \\
\hline TNL (\% intake) & $58.81 \pm 1.01^{\mathrm{a}}$ & $58.72 \pm 0.89^{\mathrm{a}}$ & $60.02 \pm 0.84^{\mathrm{a}}$ \\
\hline TNR $\left(\mathrm{mg} \mathrm{g}^{-1}\right)$ & $28.57 \pm 1.74^{\mathrm{a}}$ & $28.52 \pm 2.46^{\mathrm{a}}$ & $28.27 \pm 2.31^{\mathrm{a}}$ \\
\hline TNR (\% intake) & $41.19 \pm 1.01^{\mathrm{a}}$ & $41.28 \pm 0.89^{\mathrm{a}}$ & $39.98 \pm 0.84^{\mathrm{a}}$ \\
\hline
\end{tabular}

Superscript letters indicate intergroup statistical differences. Means \pm standard deviation of data for triplicate groups with different superscripts in the same row differ significantly (One way ANOVA and Duncan's multiple range test, $P<0.05)$.

TNI $($ total nitrogen intake $)(\mathrm{mgN} / \mathrm{g}$ production $)=($ Protein intake $/ 6.25) /$ (FBW - IBW)

TNL (total nitrogen loss) $(\mathrm{mg} / \mathrm{g}$ production $)=($ Nitrogen intake $(\mathrm{g})-$ Nitrogen retained(g))/(FBW - IBW)

TNR (total nitrogen retention) $(\mathrm{mg} / \mathrm{g}$ production $)=($ total $\mathrm{g}$ protein retained in fish/6.25)/(FBW - IBW)

fish species [29]. Fish meal was replaced with soybean meal up to $20 \%$ level in turbot diets without amino acid supplementation and no adverse effects on fish performance or feed utilization have been recorded in the present study. Similar findings were reported for yellowtail [49], gilthead seabream [29, 34], olive flounder [9], and Black Sea turbot [11, 12], while higher soybean meal incorporation of $25 \%$ to $50 \%$ were reported in Japanese flounder [23, 24], Atlantic halibut [4, 17], Atlantic turbot [10], and in yellow tail [42].

Commercial scale farming of Black sea turbot which is an alternative marine fish species is a new issue for the aquaculture industry, and knowledge about the nutritional requirement of this species is still scarce. To our knowledge so far, there is little information on the use of alternative protein sources in diets for Black Sea turbot [11, 12, 20, 44, 50], and these studies were mainly carried out by our research group. Furthermore, as far as we know, there are also only few studies published on the effectiveness of soy products as a dietary protein source in Atlantic turbot. Day and Plascencia-Gonzalez [10] reported that inclusion of soy protein concentrate up to $25 \%$ replacement of fish meal, without amino acid supplementation, did not statistically reduce fish growth and feed utilization, but that supplemental dietary methionine and lysine improved the utilization of soy protein concentrate, but this finding was not statistically significant. In Black Sea turbot, Ergün et al. [11] reported that replacing FM protein by SBM up to $20 \%$ did not affect growth performance, nutrient utilization and nitrogen retention. Ergün et al. [11] worked on smaller fish size of about $18 \mathrm{~g}$ under winter conditions. In the present study, however, fish was grown from about $30 \mathrm{~g}$ to 70 $\mathrm{g}$ and differently than the previous study, water temperature
Table 6. Muscle proximate composition of Black Sea turbot fed experimental diets in which fish meal protein was partially replaced by soybean meal protein.

\begin{tabular}{lrrrr}
\hline \multicolumn{1}{c}{$\%$} & \multicolumn{1}{c}{ Initial } & \multicolumn{1}{c}{ FM100 } & \multicolumn{1}{c}{ SBM10 } & SBM20 \\
\hline Moist (wet wt) & $80.6 \pm 0.1^{\mathrm{b}}$ & $80.1 \pm 0.04^{\mathrm{a}}$ & $80.1 \pm 0.1^{\mathrm{a}}$ & $80.2 \pm 0.1^{\mathrm{a}}$ \\
CP (dry basis) & $86.5 \pm 0.4^{\mathrm{a}}$ & $86.9 \pm 0.9^{\mathrm{a}}$ & $87.2 \pm 0.6^{\mathrm{a}}$ & $86.9 \pm 0.6^{\mathrm{a}}$ \\
CL (dry basis) & $6.3 \pm 0.1^{\mathrm{a}}$ & $6.2 \pm 0.4^{\mathrm{a}}$ & $6.2 \pm 0.1^{\mathrm{a}}$ & $6.0 \pm 0.2^{\mathrm{a}}$ \\
CA (dry basis) & $6.2 \pm 0.4^{\mathrm{a}}$ & $6.1 \pm 0.3^{\mathrm{a}}$ & $5.8 \pm 0.2^{\mathrm{a}}$ & $5.8 \pm 0.1^{\mathrm{a}}$ \\
CP (wet basis) & $16.8 \pm 0.1^{\mathrm{a}}$ & $17.4 \pm 0.2^{\mathrm{b}}$ & $17.3 \pm 0.1^{\mathrm{b}}$ & $17.2 \pm 0.2^{\mathrm{b}}$ \\
\hline
\end{tabular}

Means with different superscripts in the same row differ significantly at $5 \%$ level. CP, crude protein; CL, crude lipid; CA, crude ash.

was close to optimum and ranged from 14 to $24^{\circ} \mathrm{C}$ during the course of this study carried out from May to June. Therefore it was interesting to see that fish differing in size and cultured at different water temperatures utilized SBM well up to $20 \%$ replacement level. In Ergün et al. [12], where soybean was incorporated with hazel nut meal, brown fish meal (anchovy) was used as the main protein source, however, in the present study high quality white fish meal was used according to Yigit et al. [51], in order to define the results with high quality protein sources and under better water temperature conditions. The growth performance data in the present study appeared better than those in the previous studies with low temperature and with brown fish meal diet.

These results can be attributed to the lower water temperature as could be expected and to the lower quality fish meal (brown fish meal) in the diet for Black sea turbot. Our findings are in agreement with those reported in other studies, in terms of the possible use of SBM as a partial substitute for FM in Black Sea turbot diets. Even though the diets were not supplemented with essential amino acids, almost all amino acid requirements for turbot were covered by the experimental diets, indicating that the sub-optimal amino acid balance of SBM did not lead to negative effects in fish when soybean inclusion in the diet was increased to $20 \%$. Hasimoglu et al. [20], evaluated soybean meal and locally-produced anchovy (Engraulis encrasicolus) meal as protein sources in Black Sea turbot diets, by comparing them with Alaskan fishmeal. They prepared three diets; one contained Alaskan fishmeal and the second anchovy meal. The third diet was prepared by replacing only $5 \%$ of the anchovy meal by soybean meal. Their results show that diets with anchovy meal gave poorer growth rate when compared to the diets which used Alaskan fishmeal as a protein source. Even though the partial inclusion level of soybean meal was only $5 \%$, the groups with soybean inclusion showed the worst growth performance. It is well known that the quality of plant protein sources can be improved by thermal treatment and solvent-extraction [6], and the protein quality of anchovy meal can also differ from source to source. Furthermore, Yigit et al. [51] suggested the use of white fishmeal instead of brown fishmeal in turbot diets based on their findings of ammonia-N excretion rates after feeding. Hence these 
suggestions were followed in the present study and high quality white fishmeal (whiting meal, $710 \mathrm{~g} \mathrm{~kg}^{-1}$ crude protein) was used as the sole protein source in the control diet, whereas the other diets with soybean meal inclusion used defatted soybean meal, which is expected to have a higher digestibility than those without any treatment (heat or solvent-extraction). These conditions might have led to the present findings, different than the previous study by Hasimoglu et al. [20] on Black Sea turbot.

The amounts of lipid contained in diets with up to $20 \%$ replacement meet the essential fatty acid requirements of turbot, estimated at $8.0 \mathrm{~g} \mathrm{~kg}^{-1}$ by Gatesoupe et al. [15] or $6.0 \mathrm{~g} \mathrm{~kg}^{-1}$ by Léger et al. [26].

In the present study, no palatability problem was apparent for any of the diets and similar feed consumption was recorded for all SBM levels used, indicating that available energy contents in the diets with SBM inclusion were sufficient in all test diets. This is in agreement with Robaina et al. [34] but disagree with Venou et al. [46], who reported increased feed consumption as dietary SBM inclusion increased, which was attributed to the possibly reduced available energy content as SBM inclusion increased.

In the present study, the SGR, FCR and PERs were not significantly reduced with increasing SBM inclusion up to a level of $20 \%$, showing similarity to the findings of Day and Plascencia-Gonzalez [10], who reported no significant difference in final weight, SGR, FCR and PERs in Atlantic turbot fed diets with soy protein concentrate inclusion up to $25 \%$ level. Our findings for FCR and PER also fell within the range reported by Fournier et al. [13, 14] in Atlantic turbot and Turker et al. [44] and Yigit et al. [50] in Black Sea turbot, which were fed diets where white fishmeal was substituted by a mixture of plant proteins or poultry by-product meal, respectively. The data of our control group, which used white fishmeal only, were slightly lower than those reported by Hasimoglu et al. [20] for Black Sea turbot fed diets with Alaskan fishmeal as the sole protein source, but in overall our values were higher than their groups fed with anchovy meal diets.

Generally, an increase in ammonia nitrogen excretion is coupled with a decrease in protein efficiency and such a pattern has been reported in several studies on fish meal substitution by plant protein or animal protein sources (Robaina et al. [34], Fournier et al. [13], Turker et al. [44], Yigit et al. [50], Ergün et al. [11, 12]. In the present study, a slight increase in the nitrogen losses and a decline in protein efficiency were observed when the dietary inclusion level of SBM increased to $20 \%$, however, these differences were not significant. Nitrogen excretion were not affected by the inclusion of $20 \%$ SBM, supporting the results of the growth parameters. Growth, feed utilization or nitrogen budget values of Black Sea turbot in the present study are comparable to those of various studies on turbot nutrition $[6,10-14,33,45,50]$.

Digestibility coefficients were not determined in the present study however, the similarities in nitrogen retention in all groups suggest that the availability of protein in $20 \%$ replacement diet was similar to that of the control diet. In the present study, the findings regarding nitrogen retention are in close agreement with those reported by Burel et al. [6] (28-36\% of intake), Van Ham et al. [45] (about 30-34\% of intake), Regost et al. [33] (35-39\% of intake) and Fournier et al. [14] (36-42\% of intake) in Atlantic turbot; and Turker et al. [44] (38-40\% of intake), Yigit et al. [50] (39-41\% of intake), Ergün et al. [11, 12] (37-40\% and 38-43\% of intake, respectively) in Black Sea turbot fed diets with incorporated plant protein sources and poultry by-product meal. However, our results concerning nitrogen retention are higher than those reported by Fournier $e t$ al. [13] (22-24\% of intake) in Atlantic turbot.

Muscle tissue composition of Black sea turbot was similar in all groups and was not affected by SBM inclusion level which is in agreement with several studies on other fish species $[8,17,24,29,31,46]$. The slight increase of moisture in the muscle tissue of fish fed diets with increasing SBM inclusion resulted in a negative correlation to muscle tissue lipid content, i.e. a slight decrease was accompanied when SBM inclusion increased, representing the converse relation between moisture and lipid contents in the muscle tissue. A similar finding was also reported by Hasimoglu et al. [20] in Black Sea turbot. A slight decrease has been observed in the ash content of muscle tissue with SBM inclusion however this was also not significant.

As a conclusion, the present study indicates that up to $20 \%$ defatted SBM may be added to young Black Sea turbot diets without adverse effects on growth performance and feed efficiency. This level of incorporation allowed $18 \%$ reduction of the fish meal content in the diet. Further studies are necessary to investigate SBM inclusion levels of more than $20 \%$ in diets for young Black Sea turbot with and without amino acid supplementation. It is advisable to consider the processing methods of soybean meal that also affects the quality of the product, and so its effectiveness and utilization in the diet.

\section{ACKNOWLEDGMENTS}

We are very grateful to Prof. Dr. Muammer ERDEM (Dean of Fisheries Faculty, Ondokuz Mayis University, Sinop-Turkey) for his valuable advice and support throughout the study. The authors wish to acknowledge JAPAN International Cooperation Agency (JICA), Trabzon Central Fisheries Research Institute (CFRI), and Assoc. Prof. Dr. Emin ÖZDAMAR from JICA Office in Ankara, Turkey, for supporting the experimental animals. We wish to thank Abalioglu Feed Company in Denizli-Turkey for donating the soybean meal product used in the study.

\section{REFERENCES}

1. AOAC, Official Methods for Analysis, 14th Ed., Association of Official Analytical Chemists, Washington, USA (1984).

2. Aoki, H., Furuichi, M., Watanabe, K., Satoh, S., Yamagata, Y., and 
Watanabe, T., "Use of low or non-fish meal diets for red sea bream," Suisanzoshoku, Vol. 48, pp. 65-72 (2000).

3. Aoki, H., Shimazu, H., Fukushige, T., Akano, H., Yamagata, Y., and Watanabe, T., "Flesh quality in red sea bream fed with diet containing a combination of different protein sources as total substitution for fish meal," Bulletin of the Fisheries Research Institute of Mie, Vol. 6, pp. 47-54 (1996)

4. Berge, G. E., Grisdale-Helland, B., and Helland, S. J., "Soy protein concentrate in diets for Atlantic halibut (Hippoglossus hippoglossus)." Aquaculture, Vol. 178, pp. 139-148 (1999).

5. Bromley, P. J., "Effect of dietary protein, lipid and energy content on the growth of turbot (Scophthalmus maximus L.)." Aquaculture, Vol. 19, pp. 359-369 (1980).

6. Burel, C., Boujard, T., Kaushik, S. J., Boeuf, G., Van Der Geyten, S., Mol K. A., Kühn, E. R., Quinsac, A., Krouti, M., and Ribaillier D., "Potential of plant-protein sources as fish meal substitutes in diets for turbot (Psettc maxima): Growth, nutrient utilization and thyroid status," Aquaculture, Vol. 188, pp. 363-382 (2000).

7. Cacerez-Martinez, C., Cadena-Roa, M., and Metailler, R., "Nutritional requirements of turbot (Scophthalmus maximus): I. A preliminary study of protein and lipid utilization," Journal of the World Mariculture Society, Vol. 15, pp. 191-202 (1984).

8. Carter, C. G. and Hauler, R. C., "Fish meal replacement by plant meals in extruded feeds for Atlantic salmon, Salmo salar L.," Aquaculture, Vol. 185, pp. 299-311 (2000).

9. Choi, S. M., Wang, X., Park, G. J., Lim, S. R., Kim, K. W., Bai, S. C., and Shin, I. S., "Dietary dehulled soybean meal as a replacement for fish meal in fingerling and growing olive flounder Paralichthys olivaceus (Temminck et Schlegel)," Aquaculture Research, Vol. 35, pp. 410-418 (2004).

10. Day, O. J. and Plascencia-González, H. G., "Soybean protein concentrate as a protein source for turbot Scophthalmus maximus L.," Aquaculture Nutrition, Vol. 6, pp. 221-228 (2000).

11. Ergün, S., Yigit, M., Türker, A., and Harmantepe, B., "Partial replacement of fish meal by defatted soybean meal in diets for black sea turbot (Psetta maeotica): Growth and nutrient utilization in winter," Israeli Journal of Aquaculture-Bamidgeh, Vol. 60, pp. 175-182 (2008a).

12. Ergün, S., Yigit, M., Turker, A., and Harmantepe, B., "Incorporation of soybean meal and hazelnut meal in diets for Black Sea turbo (Scophthalmus maeoticus)," Israeli Journal of Aquaculture-Bamidgeh, Vol. 60, pp. 27-36 (2008b).

13. Fournier, V., Gouillou-Coustans, M. F., Metailler, R., Vachot, C., Moriceau, J., Le Delliou, H., Huelvan, C., Desbruyeres, E., and Kaushik, S. J., "Excess dietary arginine affects urea excretion but does not improve $\mathrm{N}$ utilization in rainbow trout Oncorhynchus mykiss and turbot Psetta maxima," Aquaculture, Vol. 217, pp. 559-576 (2003).

14. Fournier, V., Huelvan, C., and Desbruyeres, E., "Incorporation of a mixture of plant feedstuffs as substitute for fish meal in diets of juvenile turbot (Psetta maxima)," Aquaculture, Vol. 236, pp. 451-465 (2004).

15. Gatesoupe, F. J., Léger, C., Métailler, R., and Luquet, P., "Alimentation lipidique de turbot (Scophthalmus maximus L.): I. Influence de la longueur de chaîne des acides gras de la série w3," Annals of Hydrobiology, Vol. 8, pp. 89-97 (1977).

16. Gomes, E., Dias, J., and Kaushik, S. J., Improvement of feed intake through supplementation with an attractant mix in European seabass fed plant-protein rich diets," Aquatic Living Resources, Vol. 10, pp. 385-389 (1997).

17. Grisdale-Helland, B., Helland, S. J., Baeverfjord, G., and Berge, G. M., "Full-fat soybean meal in diets for Atlantic halibut: growth, metabolism and histology," Aquaculture Nutrition, Vol. 8, pp. 265-270 (2002).

18. Guillaume, J., Coustans, M. F., Metailler, R., and Person-Le Ruyet, J., "Flatfish, turbot, sole and plaice," in: Wilson, R. P. (Ed.), Handbook of Nutrient Requirement of Finfish, CRC Press, Boston, pp. 77-82 (1991).

19. Halver, J. E., Fish Nutrition. 2nd Ed., Academic Press, USA, pp. 733-734 (1991).

20. Hasimoglu, A., Erteken, A., Kino, S., and Nakagawa, N., "Evaluation of Anchovy meal and soybean meal as dietary protein sources for the Black
Sea turbot, Psetta maxima," Israeli Journal of Aquaculture-Bamidgeh, Vol. 59, pp. 73-80 (2007)

21. Kaushik, S., "Whole body amino acid composition of European seabass (Dicentrarchus labrax), gilthead seabream (Sparus aurata) and turbot (Psetta maxima) with an estimation of their IAA needs," Aquatic Living Resources, Vol. 11, pp. 351-358 (1998).

22. Kaushik, S. J., Cravedi, J. P., Lalles, J. P., Sumpter, J., Fauconneau, B., and Laroche M., "Partial or total replacement of fish meal by soybean protein on growth, protein utilization, potential estrogenic or antigenic effects, cholesterolemia and flesh quality in rainbow trout, (Oncorhynchus mykiss)," Aquaculture, Vol. 133, pp. 257-274 (1995).

23. Kikuchi, K., "Use of defatted soybean meal as a substitute for fish meal in diets of Japanese flounder (Paralichthys olivaceus)," Aquaculture, Vol. 179, pp. 3-11 (1999).

24. Kikuchi, K., Furuta, T., and Honda, H., "Utilization of soybean meal as a protein source in the diet of juvenile Japanese flounder (Paralichthys olivaceus)," Suisanzoshoku, Vol. 42, pp. 601-604 (1994).

25. Kissil, G. W., Lupatsch, I., Higgs, D. A., and Hardy, R. W., "Dietary substitution of soy and rapeseed protein concentrates for fish meal, and their effects on growth and nutrient utilization in gilthead seabream Sparus aurata L.," Aquaculture Research, Vol. 31, pp. 595-601 (2000).

26. Léger, C., Gatesoupe, F. J., Métailler, R., Luquet, P., and Fremont, L., "Effect of dietary fatty acids differing by chain length and $\omega$ series on the growth and lipid composition of turbot Scophthalmus maximus L.," Comparative Biochemistry and Physiology, Vol. 64B, pp. 345-350 (1979).

27. Masumoto, T., Tamura, B., and Shimeno, S., "Effects of phytase on bioavailability of phosphorus in soybean meal-based diets for Japanese flounder Paralichthys olivaceus," Fisheries Science, Vol. 67, pp. 1075-1080 (2001).

28. Naylor, R. L., Goldburg, R. J., Primavera, J. H., Kautsky, N., Beveridge, M. C. M., Clay, J., Folke, C., Lubchenco, J., Mooney, H., and Troell, M., "Effect of aquaculture on world fish supplies," Nature, Vol. 405, pp. 1017-1024 (2000).

29. Nengas, I., Alexis, M. N., and Davies, S. J., "Partial substitution of fishmeal with soybean meal products and derivatives in diets for gilthead seabream Sparus aurata (L.)," Aquaculture Research, Vol. 27, pp. 147-156 (1996).

30. Refstie, E., Korsøen, Ø. J., Storebakken, T., Baeverfjord, G., Lein, I., and Roem, A. J., "Differing nutritional responses to dietary soybean meal in rainbow trout Oncorhynchus mykiss and Atlantic salmon Salmo salar," Aquaculture, Vol. 190, pp. 49-63 (2000).

31. Refstie, S., Storebakken, T., Baeverfjord, G., and Roem, A. J., "Long-term protein and lipid growth of Atlantic salmon (Salmo salar) fed diets with partial replacement of fish meal by soy protein products at medium or high lipid level," Aquaculture, Vol. 193, pp. 91-106 (2001).

32. Regost, C., Arzel, J., and Kaushik, S. J., "Partial or total replacement of fish meal by corn gluten meal in diet for turbot (Psetta maxima)," Aquaculture, Vol. 180, pp. 99-117 (1999).

33. Regost, C., Arzel, J., Robin, J., Rosenlund, G., and Kaushik, S. J., "Total replacement of fish oil by soybean or linseed oil with a return to fish oil in turbot (Psetta maxima) 1. Growth performance, flesh fatty acid profile, and lipid metabolism," Aquaculture, Vol. 217, pp. 465-482 (2003).

34. Robaina, L., Izquierdo, M. S., Moyano, F. J., Socorro, J., Vergara, J. M., Montero, D., and Fernandez-Palacios, H., "Soybean and lupin seed meals as protein sources in diets for gilthead sea bream (Sparus aurata): nutritional and histological implications," Aquaculture, Vol. 130, pp. 219-233 (1995).

35. Shimeno, S., Hosokawa, H., Kumon, M., Masumoto, T., and Ukawa, M., "Inclusion of defatted soybean meal in diet for fingerling yellowtail," Nippon Suisan Gakkaishi, Vol. 58, pp. 1319-1325 (1992a).

36. Shimeno, S., Hosokawa, H., Yamane, R., Masumoto, T., and Ueno, S.-I., "Change in nutritive value of defatted soybean meal with duration of heating time for young yellowtail," Nippon Suisan Gakkaishi, Vol. 58, pp. 1351-1359 (1992b).

37. Shimeno, S., Kumon, M., Ando, H., and Ukawa, M., "The growth performance and body composition of young yellowtail fed with diets 
containing defatted soybean meal for a long period," Nippon Suisan Gakkaishi, Vol. 59, pp. 821-825 (1993).

38. Shimeno, S., Ruchimat, T., Matsumoto, M., and Ukawa, M., "Inclusion of full fat soybean meal in diet for fingerling yellowtail," Nippon Suisan Gakkaishi, Vol. 63, pp. 70-76 (1997).

39. Tacon, A. G. J. and Metian, M., "Global overview on the use of fish meal and fish oil in industrially compounded aquafeeds: Trends and future prospects" Aquaculture, Vol. 285, pp. 146-158 (2008).

40. Takagi, S., Hosokawa, H., Shimeno, S., Maita, H., Ukawa, M., and Ueno, S., "Utilization of soy protein concentrate in a diet for red sea bream Pagrus major," Suisanzoshoku, Vol. 47, pp. 77-87 (1999).

41. Takagi, S., Shimeno, S., Hosokawa, H., and Ukawa, M., "Effect of lysine and methionine supplementation to a soy protein concentrate diet for red sea bream Pagrus major," Fisheries Science, Vol. 67, pp. 1088-1096 (2001).

42. Tomás, A., De La Gándara, F., Garcia-Gomez, A., Pérez, L., and Jover, M., "Utilization of soybean meal as an alternative protein source in the Mediterranean yellowtail, Seriola dumerili," Aquaculture Nutrition, Vol. 11, pp. 333-340 (2005).

43. Tulli, F., Ramelli, M., Tibaldi, E., Manetti, F., Volpatti, D., and Galcotti, M., "Feeding seabass (Dicentrarchus labrax) juveniles with soybean products Effects on growth, feed utilization, serological response and non-specific defence," Bollettino Societa Italiana di Patologia Ittica, Vol. 12, pp. 3-9 (2000).

44. Turker, A., Yigit, M., Ergun, S., Karaali, B., and Erteken, A., "Potential of poultry by-product meal as a substitute for fishmeal in diets for Black Sea turbot Scophthalmus maeoticus: Growth and nutrient utilization in winter," Israeli Journal of Aquaculture-Bamidgeh, Vol. 57, pp. 49-61 (2005).

45. Van Ham, E. H., Berntssen, M. H. G., Imsland, A. K., Parpoura, A. C., Wendelaar Bonga, S. E., and Stefansson, S. O., "The influence of temperature and ration on growth, feed conversion, body composition and nutrient retention of juvenile turbot (Scophthalmus maximus)," Aquaculture, Vol. 217, pp. 547-558 (2003).

46. Venou, B., Alexis, M. N., Fountoulaki, E., and Haralabous, J., "Effects of extrusion and inclusion level of soybean meal on diet digestibility, performance and nutrient utilization of gilthead sea bream (Sparus aurata)," Aquaculture, Vol. 261, pp. 343-356 (2006).

47. Watanabe, T., Takeuchi, T., Satoh, S., Ida, T., and Yaguchi, M., "Development of low protein-high energy diets for practical carp culture with special reference to reduction of total nitrogen excretion," Nippon Suisan Gakkaishi, Vol. 53, pp. 1413-1423 (1987).

48. Watanabe, T., Takeuchi, T., Satoh, S., Wang, K. W., Ida, T., Yaguchi, M., Nakada, M., Amano, T., Yoshijima, S., and Aoe, H., "Development of practical carp diets for reduction of total nitrogen loading on water environment," Nippon Suisan Gakkaishi, Vol. 53, pp. 2217-2225 (1987).

49. Watanabe, T., Viyakarn, V., Kimura, H., Ogawa, K., Okamoto, N., and Iso, N., "Utilization of soybean meal as a protein source in a newly developed soft-dry pellet for yellowtail," Nippon Suisan Gakkaishi, Vol. 58, pp. 1761-1773 (1992)

50. Yigit, M., Erdem, M., Koshio, S., Ergün, S., Türker, A., and Karaali, B., "Substituting fish meal with poultry by-product meal in diets for Black Sea turbot Psetta maeotica," Aquaculture Nutrition, Vol. 12, pp. 340-347 (2006).

51. Yigit, M., Koshio, S., Aral, O., Karaali, B., and Karayucel, S., “Ammonia nitrogen excretion rate-An index for evaluating protein quality of three feed fishes for the Black Sea turbot," Israeli Journal of AquacultureBamidgeh, Vol. 55, pp. 69-76 (2003).

52. Yigit, M., Yardim, Ö., and Koshio, S., "The protein sparing effects of high lipid levels in diets for rainbow trout (Oncorhynchus mykiss, W. 1792) with special reference to reduction of total nitrogen excretion," Israeli Journal of Aquaculture-Bamidgeh, Vol. 54, pp. 79-88 (2002). 